\title{
Article \\ Planning Adaptation: Accommodating Complexity in the Built Environment
}

\author{
Kevin Muldoon-Smith * and Leo Moreton \\ Architecture and Built Environment, Northumbria University, UK \\ * Corresponding author (k.muldoon-smith@northumbria.ac.uk)
}

Submitted: 10 June 2021 | Accepted: 7 October 2021 | Published: 11 January 2022

\begin{abstract}
Obsolescence and vacancy are part of the traditional building life cycle, as tenants leave properties and move to new ones. Flux, a period of uncertainty before the establishment of new direction, can be considered part of building DNA. What is new, due to structural disruptions in the way we work, is the rate and regularity of flux, reflected in obsolescence, vacancy, and impermanent use. Covid-19 has instantly accelerated this disruption. Retail failure has increased with even more consumers moving online. While employees have been working from home, rendering the traditional office building in the central business district, at least temporarily, obsolete. This article reflects on the situation by reporting findings from an 18-month research project into the practice of planning adaptation in the English built environment. Original findings based on interviews with a national sample of local authority planners, combined with an institutional analysis of planning practice since the 1947 Town and Country Planning Act, suggest that the discipline of planning in England is struggling with the reality of flux. There is a demand for planning to act faster, due to the speed of change in the built environment, and liberal political concerns with planning regulation. This is reflected in relaxations to permitted development rules and building use categories. However, participants also indicate that there is a concurrent need for the planning system to operate in a more measured way, to plan the nuanced complexity of a built environment no longer striated by singular use categories at the local level. This notion of flux suggests a process of perpetual change, turbulence, and volatility. However, our findings suggest that within this process, there is a temporal dialectic between an accelerating rate of change in the built environment and a concomitant need to plan in a careful way to accommodate adaptation. We situate these findings in a novel reading of the complex adaptive systems literature, arguing that planning practice needs to embrace uncertainty, rather than eradicate it, in order to enable built environment adaptation. These findings are significant because they offer a framework for understanding how successful building adaptation can be enabled in England, moving beyond the negativity associated with the adaptation of buildings in recent years. This is achieved by recognizing the complex interactions involved in the adaptation process between respective stakeholders and offering an insight into how respective scales of planning governance can coexist successfully.
\end{abstract}

\section{Keywords}

adaptation; built environment; complexity; flux; temporality; urban planning

\section{Issue}

This article is part of the issue "City as Flux: Interrogating the Changing Nature of Urban Change" edited by Aseem Inam (Cardiff University).

(C) 2022 by the author(s); licensee Cogitatio (Lisbon, Portugal). This article is licensed under a Creative Commons Attribution 4.0 International License (CC BY).

\section{Introduction}

This aim of this article is to consider how the urban planning system can plan for the continual adaptation (the process by which a building changes to accommo- date new user demands) of the existing built environment in the face of increasing and recurrent manifestations of building vacancy and obsolescence. It considers this through the lens of local authority planning in England. Original findings are based on interviews with 
a national sample of local authority planners, combined with an institutional analysis of planning practice since the 1947 Town and Country Planning Act. Findings are situated within the conceptual perspective of complex adaptive systems (CAS). The article argues that the built environment, and the planning system within which it sits, should be considered, and managed, as part of a CAS rather than a static domain that needs to be simplified.

Obsolescence and vacancy have always been part of the building life cycle, as tenants leave properties and move to new ones-flux, a period of uncertainty before the establishment of new direction, can be considered part of building DNA. Buildings are produced in response to socio-economic circumstances to meet changes in demand. As that demand evolves through economic restructuring, technical innovation, and social change, existing buildings and uses become obsolete and new buildings and uses are required to replace them (Henneberry, 2017). This can be seen in a variety of contexts: through revisioning of existing housing schemes, changes from office to residential use, historic buildings as they seek viable futures, and even power stations being reimagined as art galleries.

What is new, however, is the rate and regularity of obsolescence and vacancy (Armstrong et al., 2021; Muldoon-Smith \& Greenhalgh, 2017). Traditionally, a typical office lease would be 20-25 years long with full repairing and insurance obligations placed on the tenant. In recent years, a typical lease would be $2-3$ years long and increasingly flexible as tenants demand the ability to expand or contract their business models without the restriction of a long-term property agreement. The retail built environment, in particular, was already under disruption from the internet, while the office built environment was already being pressured to reconfigure as a place to collaborate and create, alongside employees working remotely from home. Covid-19 has instantly accelerated this disruption, changing the way we utilize many of our buildings. Retail failure has sped up, with even more consumers moving online. Most employees have been working from home since March 2020, which has rendered the traditional office building in the central business district (CBD) obsolete, at least temporarily. Whole highstreets and shopping centers now lie vacant, and it is still uncertain if workers will return to CBD locations in the same way as before.

This has led to increased consideration of how the built environment can adapt to better reflect and accommodate the increasingly dynamic needs of society and the economy. In the article, flux is framed within the recent emphasis placed on temporality, transience, and permanence in the urban built environment (Henneberry, 2017); the politics of time (Raco et al., 2018); increased levels of vacant land and premises in the post-industrial city (Burkholder, 2012); a consequent engagement with DIY, guerrilla, and tactical urbanism (Deslandes, 2013); and temporary and informal uses (Bishop \& Williams, 2012; Colomb, 2012; Oswalt et al.,
2013) alongside the pragmatic steps involved in transferring a temporary activity into a mainstream process (Andres, 2013).

However, it is important to note that this new engagement with arguably necessary change is not unanimously received. Built environment professionals and planners tend to be trained to view the city as an object that is planned, designed, and built according to definitive visions, and therefore struggle with turbulent and dynamic change. For example, the political institutions and governance regimes of the built environment, often enacted through the urban planning profession via building regulations, use classifications, zones, and land use plans, often reinforce static conceptualizations of the built environment.

Those associated with the traditional, stable view of work and life have defended established business models vehemently-with those working from home, or exploring new ways of working, assumed to be returning to the CBD after Covid-19 (Mahy, 2021), even scaremongering that it will lead to jobs being outsourced (O'Connor, 2020). Influential Goldman Sachs CEO, David Soloman, has labelled working from home an "aberration" ("Goldman Sachs," 2020, para. 1), while WeWork CEO, Sandeep Mathrani, declared "those who are least engaged at work are very comfortable working from home" (Frishberg, 2021, para. 5). Perhaps this situation is understandable when we consider that how we chose to live and work is not only a personal choice. The choices that we make and how much we are willing to pay via rent and purchase prices add up to market shaping message that is broadcast across development appraisals and construction choices. Landlords and associated businesses obviously have a vested interest in lobbying for a return to the 9 to 5 business model, as it underpins the rents of most traditional properties in CBD locations.

Nevertheless, internationally, society is asking questions that speak of a growing public awareness that we have become profoundly disconnected from buildings, pigeonholed into one building use or the next. These re-evaluations then mask interrelated questions of how we should plan, construct, and use our land and buildings in response to this new volatility. Often these questions fall into reductionist binaries relating to more or less planning, better or worse quality buildings, stability and transience, and object and agent. However, rarely is emphasis placed upon the actual process of built environment adaptation, particularly how it can be achieved successfully. To respond to this situation, an underlying argument in this article is that instead of polarized dualism, flux, and in the case of this article, built environment adaptation, is a complex adaptive system.

This situation is considered through the lens of urban planning in England, as it struggles to react quickly to: (a) dynamic changes in the use and demand of the built environment, and (b) the necessarily slower need to plan for the complex implications of volatility amidst a political context of deregulation. Indeed, much of the 
current adaptation discussion in England is wrapped up in narratives of simplicity and the removal of regulation and wider neo-liberal arguments of deregulation (Tewdwr-Jones, 2012). This can be seen in the contemporary political planning narrative in England where perceived radical planning reform will "build better and build greener but we will also build faster" in order to create a planning system suitable for the 21st century (Johnson, 2020). We argue the opposite: In order for the existing built environment to adapt, there needs to be an element of structure and local planning engagement to frame and enable successful adaptation.

To inform this situation, the authors argue that more focus should be placed on the planning system itself, the system of regulations and institutions that govern adaptation in the built environment-in particular, how the planning system can govern a built environment in a permanent state of dynamic flux. The authors center the research in the CAS literature (Skrimizea et al., 2018). In this article, a CAS compromises a number of agents (in this research this could comprise tenants, planners, developers, financiers, city managers) who all have their own objectives and decision-making frameworks which evolve over time. All of these agents interact with each other over time, to form a whole that is more than the sum of the individual agent objectives. The contention is therefore that it is not only planning scholars who should focus on complexity, rather planning practitioners at various scales in government, landlords, investors, and tenants-all of whom have a stake in adapting the built environment should all adopt a complexity perspective.

The complexity perspective considers the world to be dynamic, changing, and inherently uncertain, and is underpinned by the assertion that you cannot understand such a system by looking at its individual parts or prioritize one agent or factor. This position: (a) is suggestive of the current turbulence taking place in the built environment, and (b) indicates that simplifying the way we regulate the built environment and considering it through a static perspective (de Roo, 2000, 2003) will lead to missed opportunity, seen through recent poor examples of office to residential conversion activity which has arguably favored the developer without considering quality nor how local place needs to be reconstituted to accommodate adaptation (Clifford et al., 2018). In this sense, complexity in the use of the built environment does not remove the need for planning, rather it demands a more nuanced planning system that acknowledges and seeks to enable the current fluidity in land and built environment interactions, in contrast to traditional conceptions of the planning system (and supporting theories) that have been founded in static and simplified perspectives of the land and built environments (de Roo, 2010; Skrimizea et al., 2018).

Static ideas of complexity are illustrated by planning use categories (in the English planning tradition) and land use zones (in the European and North American planning tradition). Relatively speaking, these regulatory tools stood the test of time while land and building use remained relatively static and slow changing within the traditional differentiation of residential, office, retail, leisure, and industrial use. More recently, planning scholars (Boonstra \& Boelens, 2011; Byrne, 1998; de Roo \& Rauws, 2012; Innes \& Booher, 2010; Portugali, 2011, 2012; Sengupta, 2011; Sengupta et al., 2016; Skrimizea et al., 2018) are contesting the static consideration of the planning environment and forwarding a perspective of society that is founded within ideas of complex systems, the unpredictable structures that emerge from such systems, and how systems (in this article building users) interact with their built environments. Suzuki (2007, p. 29) argues that at some point "a chaotic system of individuals undergoes a transition to order. And with this order, the complex system becomes highly adaptive, with a heightened capacity to respond to a constantly changing and unpredictable world." CAS recognizes uncertainty and complexity as a natural part of the land and built environment. It is this perspective of society and the broader environment that the authors seek to evoke in their conceptualizations of the land and built environment and also the complex planning system needed to make sense of it (Baggio, 2008; Hall \& Clark, 2010; Liu et al., 2007; McGreevy \& Wilson, 2017). In other words, the urban environment (and those that use it) is an interdependent, mutually interacting CAS (Waldrop, 1992).

The next section of this article considers the current planning context in England as a backdrop for the analysis in the article. It charts the history of discretionary planning in England, as it relates to building adaptation, and the more recent reduction in planning regulation within a perceived "freeing-up" of development potential. At this point, connections are made between the English experience of building adaptation and international approaches alongside wider debates of complexity. The remainder of the article analyzes the findings from local authority planners, their perception of building adaptation, and how a complexity approach could assist this demand. In the conclusion, the underlying research question is reflected upon alongside an appraisal of limitations, in view of the positions adopted in this article and opportunities for further research.

\section{Changing Planning Context in England}

The planning system in England can largely trace its modern history back to the 1947 Town and Country Planning Act, although its genealogy stretches back to the 1700s (Booth, 2003). The central tenants of the act were to divide the current quiet enjoyment of land from its future use, which was nationalized. Henceforth, anyone carrying out new development (as opposed to the existing land or building use) would need discretionary case-by case planning consent before developing any new work. Evoking the more recent engagement with complexity in planning theory, this system of planning 
consent and development control is based upon the central principles of elasticity and flexibility, particularly the recognition that individual planning applications have their own individual complexity but that this complexity sits within a wider spatial whole. These principles have traditionally set the English tradition of planning consent apart from its zone-based European and North American counterparts (Booth, 2003, 2009). Rule based regulatory zoning systems establish hard and fast rules in relation to what can and cannot happen on land and within buildings, seen in many other international contexts across Europe, Asia, the United States, and Canada (for a comprehensive discussion of discretionary planning in England vs. zone-based systems in other parts of the world cf. Schulze-Bang \& Webb, 2020).

However, in recent years, there has been a gradual erosion of discretionary planning in England. A pro-developer model has begun to gain ascendency (Tewdwr-Jones, 2012), based in the principles of reduced planning obstacles and presumptions in favor of new development. This has led to a tension between the perspectives of discretionary planning (seen by its detractors as sluggish) and neo-liberal developer friendly planning (seen by its detractors as simplistic). This tension is well captured by Jowell $(1975$, p. 30$)$, who argues that:

What is gained in uniformity may be lost in flexibility; rules to prevent the arbitrary may encourage the legalistic; case-by-case adjudication may prevent comprehensive planning; rules that may shield the bureaucrat from pressures and allow the efficient and speedy dispatch of cases, may offend the client who desires individually tailored justice.

The pro-developer planning perspective argues that the discretionary model of planning is too complex and increases risk and uncertainty in development. This then pushes up the cost of development related capital finance and reduces innovative new uses of land and buildings. Adherents of this perspective argue for a simpler planning system, that allows market competition, greater diversity of developers and, in turn, more adaptable places. Arguments in this arena contend that the flexibility inherent in the locally focused 1947 Town and Country Planning Act has been constrained by increased legislation as local plans have been strengthened (MacGregor \& Ross, 1995) alongside the reequipment for detailed action plans, supplementary planning documents, housing and economic land availability assessments, and brownfield registers (Gallent et al., 2019; Schulze-Bang \& Webb, 2020).

The advent of the coalition government in 2010 and successive conservative governments in 2015, 2017, and 2019 has seen the 1300 pages of planning guidance in existence pre-2010 reduced to 65 pages with the advent of the National Planning Framework in 2012. This was followed in 2013 with the temporary amendment of the General Permitted Development Order, which allowed the conversion of some building use without the need for formal planning permission; the most widely used was for office to residential change of use. This permission was made permanent in 2016 and followed in 2020 by subsequent legislation to give prior approval for the demolition of redundant commercial buildings and replacement with residential use. This was then immediately proceeded by the new commercial, business, and service use class-Class $\mathrm{E}$-which came into effect in September 2020. Landlords (and business owners) now have greater flexibility to respond to changes in the trading environment and adapt without requiring planning permission. Perhaps the biggest change is that proposed in the 2020 Planning for the Future White Paper, which signals the change from a discretionary planning system, based in individual planning permission within an area-based plan system, to a rule-based system of zones. At the time of writing, this new planning rationale, defined by central government, instructs councils to simplify planning and parcel land into one of three categories (1: Growth, 2: Renewal, 3: Protection) with the "growth" and "renewal" zones suggesting outline planning permission and implicit permission to develop without formal planning procedures. However, following the appointment of a new Housing Secretary (Michael Gove) there is currently a pause in relation to the most significant planning reforms and a delay in the Planning Bill which would legislate for the proposals in the Planning for the Future White Paper. Table 1 provides a simple summary of the planning changes over the last decades as they relate to building adaptation.

The need to resolve these kinds of tensions is why the focus on change and impermanence in the government's Planning for the Future consultation-and the parallel change to Use Category $\mathrm{E}-\mathrm{is}$, in principle, to be welcomed. Previous research by Muldoon-Smith and Greenhalgh (2016) set out the need for adaptation in the built environment and the limitations of the governments Permitted Development Rights scheme for office to residential conversion. These initial findings have been more than vindicated by subsequent research from Remoy and Street (2018), Holman et al. (2017), Clifford et al. (2018), and Ferm et al. (2020) into the quality of subsequent homes. This led the government to introduce a further requirement, announced in 2020 , for all new permitted development schemes to provide adequate natural light and comply with minimum space standards set at a national level.

However, in the drive for planning simplicity, we argue that England has potentially created a planning system that is insensitive to some of the most monumental changes taking place in the built environment. In ignoring this situation, we suffer the on-going illusion that market forces will drive adaptation in the built environment, if only the public sector would step away. In response, we argue for a counterweight to this arguably roll back and roll out neo-liberal (Peck \& Tickell, 2002) planning rationale which recognizes the complexity of adapting 
Table 1. Summary of planning change relevant to building adaptation since 2010. The new National Planning Policy Framework reduced 1300 pages of planning guidance to 65 pages.

2013 Temporary amendment of the General Permitted Development Order which permitted the conversion of underused office buildings into residential change of use.

2016 Amendment of the General Permitted Development Order was made permanent.

August 2020 Prior approval for the demolition of redundant commercial buildings and redevelopment as residential use.

August 2020

Planning for the Future White Paper was published.

New commercial, business, and service use class-Class E-came into effect.

the built environment. The question we therefore pose is not whether to adapt, or not to adapt, but how best to plan for the adaptation of a complex land and built environment.

Zellner and Campbell (2015) and Sengupta et al. (2016) argue that it has taken some time for the discipline of planning to consider some issues as "complex." Subsequently, the actual mechanisms that will prove adequate to tackle complex planning issues constitute a very relevant issue still under debate (Skrimizea et al., 2018, p. 123). Skrimizea et al. (2018) go on to argue that complexity has been considered in the slightly wider domain of natural resource management (Arnold, 2010; Kato \& Ahern, 2008; van Buuren et al., 2013), where adaptive management (Arnold, 2010; Patterson et al., 2008; Terryn \& Boelens, 2013; Westley, 2002), adaptive policy making (Haasnoot et al., 2013), and adaptive governance (Dietz et al., 2003) have gained some traction.

The intention is to extend these considerations into the adaptation of the physical built environment and its urban planning. The CAS approach opens up the possibility of removing binary positions of simplified and inefficient planning, recognizing that if the built environment-and planning-is going to adapt to more dynamic socio-economic conditions it needs a more complex, rather than simplified planning and development perspective. It is hoped that the CAS perspective is not only useful to planners who wish to accommodate adaptation in place but also landlords and investors who are struggling to make sense of the hybrid world of working at home and in the place of work. While it is conceded that this position may not be attractive to those building owners who want to force workers back into the office, it is hoped that the CAS position will help smooth some of the frictions and antagonisms between scales of government, those charged with writing planning White Papers, local authority planners, developers, investors, and tenants, recognizing that all of these agents interact and influence the wider development system as a whole.

\section{Methodology}

The remainder of the article examines this gap in knowledge, namely, how can the planning profession better support the need for the built environment to adapt under conditions of complexity. Central government in England has clearly given considerable thought to adaptation in the Planning for the Future White Paper. Academics and professional groups have responded meaningfully to the proposals in the White Paper (see the recent contributions from the Town and Country Planning Association, 2020). However, it is unclear to what extent local authority planning practitioners, often seen as the cause of local inertia, have been consulted in this process. The findings attempt to fill this omission and seek to suggest how the English planning system can better support complex adaptation.

The article addresses this situation with the following research question: How can the planning system in England better support complex adaptation in the built environment? The article reflects on this question by reporting findings from an 18-month research project into the practice of planning adaptation in the built environment in England. In this research, focus is entirely on public sector planning professionals. The novelty in this research is found within giving these professionals a voice in the planning system which is increasingly defined by top-down decree from civil servants and politicians. The authors consider that these local planning professionals have meaningful insights into the practice of complex adaptation in the built environment, because they experience it on a daily basis in their local built and land environments. We recognize that by not surveying private sector planners we present a partial picture of the planning profession in England. We do not talk to private sector planners, developers, landlords, investors, or tenants and building users. In addition, we do not employ geographical analysis of the various responses. Yet, on balance, we argue that this perspective provides an original counter narrative to more regular written interventions from central government, politicians, and private developers. The missing agents within the CAS of adaptation and the potential for geographical enquiry are highlighted as an opportunity for additional study in the conclusion.

The empirical material in this article is based on a two-stage research process, where all local planning authorities in England were approached (333 local 
authorities in total) in relation to their viewpoints on the research topic. Where the same professionals were interviewed at both stages in the process, an improvised Delphi technique was used to gain consensus in viewpoint (Linstone \& Turoff, 1975). A conscious decision was taken to organically weave the participant content into the text to, where possible, create a narrative account of planning adaptation to counter the relative silence given to local planners in this debate (Etherington, 2007; Hertz, 1997). The intent behind this approach is to bring to the surface the varying types of institutional language and attitudes that texture the complexity of this process. Therefore, throughout the article, those taking part in the research are considered and referred to as research participants, rather than respondents, and all effort is made to give voice to their opinions.

The authors approached local authorities directly, rather than via Freedom of Information Request to avoid the risk of legalistic and sanitized responses. Although a relatively modest response number (specifically 31 local authorities, just under $10 \%$ of the sample), this methodological approach generated a unique sample of responses from experienced practitioners across a comprehensive geography. The planners all worked within planning policy or development control in local planning authorities with responsibility for planning applications. Most of the interviews were conducted via telephone, and latterly software-based communication platforms as Covid-19 set in. All findings were recorded, transcribed, and then coded using an analysis matrix. The analysis matrix was used to make sense of thematic coding founded within an overall grounded theory (Glaser \& Strauss, 1967) and constant comparative (Goertz \& Le Compte, 1981) form of analysis and theory development. Upon request, practitioner identities and local authority locations have been redacted in order to protect their identity (only general location information is revealed). This approach stimulated frank discussion in relation to the planning of adaptation, which might not have been possible otherwise. This empirical material is complemented by a secondary analysis of the institutions of planning governance in England, analyzing policy evolution since the 1947 Town and Country Planning Act.

The significance of this research is that it provides policy makers with a perspective to evaluate ideas in relation to planning building adaptation. For those planners involved in the day-to-day management of building transformation, the article provides an approach to understanding the wider significance of building adaptation which the researchers hope will contribute to a more knowledgeable and effective planning practice in relation to building change. Expanding knowledge in this area will help planning practitioners in mature urban areas deal with the challenges of adapting an ageing urban landscape. However, it is also hoped that this approach will help those planning practitioners dealing with the demands of accelerating urbanization in the non-western world.

\section{How Can the Planning System in England Better Support Complex Adaptation in the Built Environment?}

Changes to the English planning system since 2010, culminating in the Planning for the Future White Paper, appear to delocalize planning, favoring a blanket approach based on simplicity and state led permission in principle. However, our findings suggest that adaptation would be better supported by a different trajectory, one more associated with the original discretionary intentions of the 1947 Town and Country Planning Act combined with a perspective founded upon CAS. These findings can be encapsulated in three main areas:

(1) The need for a more locally sophisticated, nuanced planning system that is responsive to complexity (explored in Section 3.1);

(2) The demand for a slower, measured planning system that facilitates a complex built environment that is in a constant state of flux (explored in Section 3.2);

(3) The need for granular, place specific spatial planning that co-exists with central decree, rather than simplified zones within a centrally defined, permissive, and permitted planning system (explored in Section 3.3).

The participants in the research all recognized in varying degrees the need for the built environment to adapt and the gradual dissolution of fixed building use categories. However, in order to facilitate this impermanence in the built environment, the participants also noted the challenges inherent in making this a reality. They collectively argued that in order for adaptation to take place relatively quickly-one of the central tenants of the Planning for Future White Paper-there needed to be a parallel planning process that recognized the complex actor interrelationships at various scales and the place-based factors that need to be prepared to support recurrent building adaptation.

\subsection{The Case for Complexity in the Planning System}

It is important to note that planners surveyed in the study were not focused on preserving the traditional planning system in England. Like existing buildings, they recognize the need for the planning system to evolve in response to a more dynamic environment. The built environment, and the way we use it, has clearly reached a threshold. The old urban world of clear building use (and associated codes) is simply no more. In principle, the majority of participants were in favor of enhanced permitted development rights, the new Use Class $E$, and also supported the potential use of zoning. However, their greatest concern was in the lack of recognition for the complex deliverability of these principles. For example, a planner in Central London argued that: 
Deregulation has become synonymous with no regulation, which shouldn't necessarily be the case. There needs to be a balance struck through relaxation of certain elements of planning regulations within a continuing local plan-led system that recognizes local complexity. Country-wide deregulation gives no recognition to local context differences.

In the East Midlands, another planner stated that:

I feel that current policy is a blunt instrument. It does not take into account the complexity of town centers types, characteristics, and sizes. The policies fly in the face of localism and devolution.

There was a sense from participants that the real need to change the built environment was being confused with a concurrent demand for less planning. Participants instead favored a balanced approach that enhances the ability to adapt the built environment, supported by local consultation, and importantly the infrastructure to support the inevitable complexity of mixed use. Participants overwhelmingly argued that the need to adapt the built environment should not be elided and overtaken by other competing planning policy demands, such as the need to speedily increase new house building. There is clearly a demand to plan multi-functional spaces where people live, work, and conduct leisure alongside supportive amenities. This demands careful planning to account for complexity, not only simplicity and quick development. A planner in North London characterizes this situation, arguing that:

Local authority planners look at economic implications, viability, and the standards of schemes. Permitted development rights makes it easier for developers to circumvent these considerations. Poor adaptation can negatively change the dynamics of a place if local authorities cannot plan for local complexity.

Reflecting the recent arguments of Zellner and Campbell (2015), who called for planners to further develop their quantitative and computational skills in addition to negotiation and communication, several planners called for enhanced use of technology to help make the planning system more efficient but retain the focus on local complexity, arguing that the traditional planning system needs to:

Move away from exhaustive and expansive written studies and evidence costing tens of thousands of pounds at a time and years to implement, towards a more reactive data-based system that responds to real-time demands in urban areas, adapting its policies to allow for provision where it is needed and to address trends and shortfalls evident in emerging recent and relevant data. (A planner in South East England)
This echoes Zellner and Campbell (2015, p. 472), who see CAS and associated complexity sciences as an "extension and technologically-assisted enhancement of communicative action" rather than an aid to simplification of planning.

\subsection{Complex Planning}

While supportive of the principles behind recent policies that aid adaptation, findings in this study suggest that the discipline of planning is struggling with the reality of implementing the complexity associated with adaptation. Clearly, there is a demand for planning to act faster-due to the speed of change in the built environment. This is reflected in relaxations to permitted development rules and building use categories. However, there is also a concurrent need for planning to operate more circumspectly in order to plan the nuanced complexity of a built environment no longer striated by singular use categories. Reflecting the temporal dialectic suggested earlier, between an accelerating rate of change in the built environment and a concomitant need to plan in a measured way to accommodate this process, participants argued that:

There is a misconception that discretionary planning leads to piecemeal slow development; the discretionary system exists with a local plan environment which prevents this. Rather, it is the centrally imposed de-regulation that causes poor development that then needs to be retrospectively unpicked. (A planner from the West Midlands)

Much of the Planning for the Future consultation is encased in the rhetoric of development, housing growth, and acceleration. This manifestation can be linked into the policy mobilities literature which examines the techniques, narratives, and temporalties that accelerate and decelerate policy adoption (Grimwood et al., 2021; McCann, 2011; McCann \& Ward, 2013; Peck \& Theodore, 2010, 2015; Temenos \& McCann, 2013; Wood, 2015). For example, Peck and Theodore (2015) highlight the foreshortening of the policy development process and its acceleration under roll back and roll out neo-liberal notions of reform. In a certain sense, this acceleration is synonymous with the dynamic volatility-the state of flux, inherent in the current built environment.

However, Wood (2015) and Grimwood et al. (2021) supplement this perspective by distinguishing between policy adoption and implementation, the former fast but the latter gradual, "creeping, at times sluggish and sticky, and at other times loitering instead of prompt and hurried" (Wood, 2015, p. 569). While this distinction is still concerned with how polices take route in practice, rather than how policy should be implemented, in a similar way to the findings of the slow city movement (Lynch, 1973; Raco et al., 2018; Slow Movement, 2017), it helpfully distinguishes the complexity involved in adopting a faster 
planning system that accommodates adaptation but one that also needs to be implemented slowly to achieve this aim. In this sense, flux, transience, impermanence, and adaptation can be perceived as both risk and opportunity (Sengupta et al., 2016). As such, we argue that the aim of urban planning, as it relates to the adaptation of the built environment, should not be to reduce uncertainty, nor to control complexity, but to "understand and harness" these factors and develop a planning system that "coadapts" and "co-evolves" (Skrimizea et al., 2018, p. 131) alongside dynamic changes in the use of the built and urban environment (Allen, 2012; de Roo, 2007; Terryn \& Boelens, 2013).

Suggesting one avenue for this, a planner in the Southeast argued for a "'fast track' local planning system for developers that supports high quality, complex adaptation, rather than one that supports poor quality developments through the back door." This is in contrast to the recent poor examples of building adaptation, particularly office to residential conversions, which are arguably due to simplified planning policy and poor economic conditions; for example, where poor schemes have scrapped through on the margins of viability because of the removal of affordable housing requirements, infrastructure contributions, and relaxed building standards.

\subsection{Local Spatiality and Cooperation}

In these uncertain times, it can be argued that the best strategy for tackling Covid-19 seems to be local, targeted intervention as spikes develop and mutate in different complex ways (World Health Organization, 2020). Findings suggest that it is similar for built environment adaptation, which is also uncertain and dynamic. A planner from North London states that "Local authorities currently have to react to what Westminster says. The more you localize the ability to respond to the changes, the easier it becomes to manage adaptation."

In their support for adaptation, participants called for more deregulation. However, importantly, they indicated that deregulation should take place at the national level, with more emphasis given to the local scale of planning. A planner from Central London argued that:

Local planning authorities have a more detailed understanding of the issues facing their areas and are better placed to respond to adaptation. A onesize-fits-all approach doesn't work. [Unfortunately, at the moment], we are being deregulated at the local scale but regulated more at the national scale; this ties our hands.

Participants were very clear that much of the recent planning changes, particularly by subverting the National Development Order, contradicted other policy priorities around localism and devolution. However, participants confirmed that they did not refute national planning involvement if it was strategically supportive to local complexity. This indicates that local scales of planning should deal with granular context specific complexity, while national government should "set stringent quality measures [e.g., energy efficiency and domestic room sizes] to ensure that the country, as a whole, benefits from high quality development" (a planner from the East Midlands).

In making this argument, it is not our intention to over fetishize the local in favor of the national scale of government. Most-if not all-planning systems operate within varying contexts of tension between national and local scales of planning, and often additional regional and sub-national scales in between. Rather, our intention is to highlight the need for both to be recognized as a wider CAS that must come together to enable adaptation, rather than a set of individual agents with competing objectives (see Section 2 for a discussion of these tensions, as they relate to the changing nature of planning in England since 2010). The Covid-19 response displays a positive example of how national government in England has collaborated with the private sector to develop vaccines while recognizing that plans should be flexible enough to react to changing epidemiological conditions in different parts of the country, the local context, and the capacity to respond (World Health Organization, 2020).

Indeed, participants were also clear that the planning system is only one part of the complex process of adaptation in the built environment. Illustrating this, a planner from the West Midlands argued that adaptation is "also linked to regeneration, access to funding, and the market for the re-use."

Evoking this observation, Adams and Tiesdell (2010, p. 198) have argued that planners do not necessarily see themselves as market actors even though they traditionally play an important role in "shaping, regulating and stimulating market activity." In the arguably anti-planning rhetoric over the last 12 years, cooperation almost seems discredited in favor of planners protecting the bastions of quality and local areas from developers out for a quick buck. However, the authors argue that sustaining a dualism between planning regulation and market-based development is only a useful political tool for those interested in reducing the role of local planning authorities, as it allows the latter (those who want as few planning regulations as possible at the local scale) to define themselves against the former (the perceived inefficient local barriers to adaptation). Instead, research participants insist that instead of heated debate there is need for polite agreement between these opposing viewpoints. It is when planners work with developers, investors, and designers to find locally specific solutions to building obsolescence that they arguably have most impact. The CAS perspective is potentially a key enabler in this process as it fundamentally recognizes that each agent involved in the adaptation process comes together to form a greater whole, even though they have different objectives and perspectives. Currently, in 
England, politicians are portrayed as the progressive change champions while local planners and governments are being portrayed as obstructors of innovation. It is anticipated that by utilizing a more holistic perspectivealthough one that still recognizes differences of opinionadaptation can be more successful and the government can create policy recognizing that complexity can help enable adaptation, rather than prohibit it. It is also hoped that the CAS perspective gives local authority planners (and related academics) a framework to shape the adaptation debate, rather than criticizing it.

\section{Conclusion}

In response to the underlying research question in this article (How can the planning system in England better support complex adaptation in the built environment?), we argue that those involved in building adaptation-be they planners, developers, landlords, or tenants-should revisit the spirit of the 1947 Town and Country Planning Act. This is because it evokes the principles of CAS, particularly the recognition that individual planning applications, as they relate to building adaptation, are part of a wider spatial whole in terms of infrastructure requirement, quality considerations, and precedent that has been set historically. We argue that a CAS approach helps to balance the challenge of creating a planning system that is nimble enough to facilitate timely adaptation but rigorous enough to accommodate and support dynamic change in the built and spatial environment.

This contrasts with the Planning for the Future White Paper which pejoratively argues for the overturning of the discretionary-based tradition in English planning in favor of a rules-based system to obviate perceived inefficiency. We argue that enduring change comes through improving processes and shaping institutions, not temporarily overriding them through force of political will and policy acceleration.

Our findings suggest that we are potentially simplifying our approach to adaptation in the built environment just when we should be engaging with complexity in the built environment. The authors argue that there is a need to plan for an accelerated time of experimentation, as society decides how it is going to function in its built environment going forward which no longer has hard and fast rules.

Within this argument it is important to note that the authors are not against change in the planning system. We agree that inefficiency should be removed from the planning system. However, this imperative should not be conflated with the removal of complexity. Rather, we argue that a useful focus for planning the built environment is complexity itself, rather than simplification. Arguably, only by recognizing the complexity and interconnection between different scales of government, and the competing but overlapping interests of actors within the adaptation process, will the very reputation of adaptation be rejuvenated.
In considering how to contend with adaptation in the built environment it is worth noting some limitations in this article. To tackle the research question, the authors have taken a necessarily broad view of planning history in England since 1947 and the study of complexity (for a more detailed account of the evolution of planning in England since this time see Booth, 2003, 2009; for a more detailed account of planning change since 2010 see Grimwood, 2021). In addition, we have chosen to focus our enquiry on planning in England. This is a partial representation of adaptation in the international context, and we concede that there is considerable potential for comparative studies in other international locations and planning contexts. Nevertheless, we consider the current planning changes in England to form a key laboratory for the rest of the world. This is because planning in England is going through such significant structural change, with the very fabric of its legislation (and the ideas that underpin it) changing radically since 2010. Some of this change is specific to England, part of a long held conservative demand for liberty and smaller government. However, the situation is also influenced by wider international ideological currents of neo-liberalism and structural socio-economic factors associated with changing building use habits.

In addition, we have only had room to make a cursory appraisal of complexity, as it applies to planning the built environment (for a more thorough account of complexity in planning see Sengupta et al., 2016, and Skrimizea et al., 2018 , both of which were useful conceptual conduits for this article). We argue there is considerable scope for further research into how the CAS perspective can aid the development of planning practice, as it relates to the adaptation of the built environment. We also recognize that by focusing only on local authority planners we provide an incomplete picture of the stakeholders involved in the adaptation process while we also do not delve into geographical differences between the relative participants and locations surveyed. Both of these areas are certainly an opportunity for additional study.

Instead, the article aims to set out an initial conceptual position that can be used to think about how to plan for adaptation in the complex built environment while at the same time giving planners on the ground a voice in this debate. There is no magic wand for adaptation and the devil is in the detail. As Jacobs (1958) remarked, "designing a dream city is easy. Rebuilding a living one takes imagination." To this end, and despite these limitations, we consider the perspective and findings in this article a useful lens through which to understand the situation at hand. In this sense, the article should be seen as an early staging post for research into the complex planning of adaptation in the built environment-an argument that can be seen in parallel to what seems an unabated push toward conversion of buildings into new use, most recently seen in the recent announcement from the City of London Corporation that they intend to convert redundant offices into 1,500 new 
homes by 2030 ("City of London to convert offices into homes," 2020).

\section{Conflict of Interests}

The authors declare no conflict of interests.

\section{References}

Adams, D., \& Tiesdell, S. (2010). Planners as market actors: Rethinking state-market relations in land and property. Planning Theory \& Practice, 11(2), 187-207. https://doi.org/10.1080/1464935100375 9631

Allen, P. M. (2012). Cities: The visible expression of coevolving complexity. In J. Portugali, H. Meyer, E. Stolk, \& T. Ekim (Eds.), Complexity theories of cities have come of age (pp. 67-89). Springer.

Andres, L. (2013). Differential spaces, power hierarchy and collaborative planning: A critique of the role of temporary uses in shaping and making places. Urban Studies, 50(4), 759-775. https://doi.org/ $10.1177 / 0042098012455719$

Armstrong, G., Soebarto, V., \& Zuo, J. (2021). Vacancy visual analytics method: Evaluating adaptive reuse as an urban regeneration strategy through understanding vacancy. Cities, 115, Article 103220. https://doi. org/10.1016/j.cities.2021.103220

Arnold, C. A. (2010). Adaptive watershed planning and climate change. Environmental and Energy Law and Policy Journal, 5(2), 417-487.

Baggio, R. (2008). Symptoms of complexity in a tourism system. Tourism Analysis, 13(1), 1-20. https://doi. org/10.3727/108354208784548797

Bishop, P., \& Williams, L. (2012). The temporary city. Routledge.

Boonstra, B., \& Boelens, L. (2011). Self-organization in urban development: Towards a new perspective on spatial planning. Urban Research \& Practice, 4(2), 99-122. https://doi.org/10.1080/17535069. 2011.579767

Booth, P. (2003). Planning by consent: The origins and nature of British development control. Routledge.

Booth, P. (2009). Managing land-use change. Land Use Policy, 26(Suppl. 1), S154-S159. https://doi.org/ 10.1016/j.landusepol.2009.08.011

Burkholder, S. (2012). The new ecology of vacancy: Rethinking land use in shrinking cities. Sustainability, 4(6), 1154-1172. https://doi.org/10.3390/ SU4061154

Byrne, D. (1998). Complexity theory and the social sciences: An introduction. Psychology Press.

City of London to convert offices into homes in postCovid revamp. (2020, April 27). BBC News. https:// www.bbc.com/news/business-56888615

Clifford, B. P., Ferm, J., Livingstone, N., \& Canelas, P. (2018). Assessing the impacts of extending permitted development rights to office-to-residential change of use in England. Royal Institution of Chartered Surveyors.

Colomb, C. (2012). Pushing the urban frontier: Temporary uses of space, city marketing, and the creative city discourse in 2000s Berlin. Journal of Urban Affairs, 34(2), 131-152. https://doi.org/10.1111/ j.1467-9906.2012.00607.x

de Roo, G. (2000). Environmental conflicts in compact cities: Complexity, decision making, and policy approaches. Environment and Planning B: Planning and Design, 27(1), 151-162. https://doi.org/ 10.1068/b2614

de Roo, G. (2003). Environmental planning in the Netherlands: Too good to be true. Avebury.

de Roo, G. (2007). Shifts in planning practice and theory: From a functional towards a communicative rationale. In G. de Roo \& G. Porter (Eds.), Fuzzy planning: The role of actors in a fuzzy governance environment (pp. 103-114). Ashgate.

de Roo, G. (2010). Planning and complexity: An introduction. In G. de Roo \& E. Silva (Eds.), A planner's encounter with complexity (pp. 1-15). Ashgate.

de Roo, G., \& Rauws, W. (2012). Positioning planning in the world of order, chaos and complexity: On perspectives, behaviour and interventions in a nonlinear environment. In J. Portugali, H. Meyer, E. Stolk, \& T. Ekim (Eds.), Complexity theories of cities have come of age (pp. 207-220). Springer.

Deslandes, A. (2013). Exemplary amateurism: Thoughts on DIY urbanism. Cultural Studies Review, 19(1), 216-227. https://doi.org/10.5130/csr.v19i1.2481

Dietz, T., Ostrom, E., \& Stern, P. C. (2003). The struggle to govern the commons. Science, 302(5652), 1907-1912.

Etherington, K. (2007). Ethical research in reflexive relationships. Qualitative Inquiry, 13(5), 599-616. https://doi.org/10.1177/1077800407301175

Ferm, J., Clifford, B., Canelas, P., \& Livingstone, N. (2020). Emerging problematics of deregulating the urban: The case of permitted development in England. Urban Studies, 58(10), 2040-2058. https://doi. org/10.1177/0042098020936966

Frishberg, H. (2021, May 14). WeWork CEO says "least engaged" employees prefer to work from home. New York Post. https://nypost.com/2021/05/14/ least-engaged-employees-want-to-work-fromhome-wework-ceo

Gallent, N., De Magalhaes, C., Freire Trigo, S., Scanlon, K., \& Whitehead, C. (2019). Can "permission in principle" for new housing in England increase certainty, reduce "planning risk," and accelerate housing supply? Planning Theory \& Practice, 20(5), 673-688. https://doi. org/10.1080/14649357.2019.1672772

Glaser, B., \& Strauss, A. (1967). The discovery of grounded theory: Strategies for qualitative research. Aldine.

Goertz, J. P., \& Le Compte, M. D. (1981). Ethnographic research and the problem of data reduction. Anthology and Education Quarterly, 12(1), 51-70. 
Goldman Sachs: Bank boss rejects work from home as the "new normal." (2020, February 25). BBC News. https://www.bbc.com/news/business-56192048

Grimwood, G. G. (2021). Planning in England: Permitted development and change of use (Briefing Paper No. 00485). House of Commons Library.

Grimwood, R., Baker, T., Humpage, L., \& Broom, J. (2021). Policy, fast and slow: Social impact bonds and the differential temporalities of mobile policy. Global Social Policy. https://doi.org/10.1177/1468018121997809

Haasnoot, M., Kwakkel, J. H., Walker, W. E., \& ter Maat, J. (2013). Dynamic adaptive policy pathways: A method for crafting robust decisions for a deeply uncertain world. Global Environmental Change, 23(2), 485-498. https://doi.org/10.1016/j.gloenvcha.2012.12.006

Hall, A., \& Clark, N. (2010). What do complex adaptive systems look like and what are the implications for innovation policy? Journal of International Development, 22(3), 308-324. https://doi.org/10.1002/jid. 1690

Henneberry, J. (Ed.). (2017). Transience and permanence in urban development (1st ed.). Wiley.

Hertz, R. (1997). Reflexivity and voice. SAGE.

Holman, H., Mossa, A., \& Pani, E. (2017). Planning, value(s) and the market: An analytic for what comes next? Environment and Planning A: Economy and Space, 50(3), 608-626. https://doi.org/10.1177/ $0308518 \times 17749730$

Innes, J., \& Booher, D. E. (2010). Planning with complexity: An introduction to collaborative rationality for public policy. Routledge.

Jacobs, J. (1958, April). Downtown is for people. Fortune. https://fortune.com/2011/09/18/downtownis-for-people-fortune-classic-1958

Johnson, B. (2020). PM economy speech: 30 June 2020 [Speech transcript]. GOV.UK. https://www.gov.uk/ government/speeches/pm-economy-speech-30june-2020

Jowell, J. (1975). Law and bureaucracy: Administrative discretion and the limits of legal action. Dunellen.

Kato, S., \& Ahern, J. (2008). Learning by doing: Adaptive planning as a strategy to address uncertainty in planning. Journal of Environmental Planning and Management, 51(4), 543-559. https://doi.org/10.1080/ 09640560802117028

Linstone, H. A., \& Turoff, M. (1975). The Delphi method techniques and applications. Addison-Wesley.

Liu, J., Dietz, T., Carpenter, S. R., Alberti, M., Folke, C., Moran, E., Pell, A. N., Deadman, P., Kratz, T., Lubchenco, J., Ostrom, E., Ouyang, Z., Provencher, W., Redman. C. I., Schneider, S. H., \& Taylor, W. W. (2007). Complexity of coupled human and natural systems. Science, 317(5844), 1513-1516. https://doi. org/10.1126/science.1144004

Lynch, K. (1973). What time is this place? MIT Press.

MacGregor, B., \& Ross, A. (1995). Master or servant? The changing role of the development plan in the British planning system. The Town Planning Review, 66(1),
41-59.

Mahy, E. (2021, June 8). "Five-day office week will become the norm again." BBC News. https://www. bbc.com/news/business-57339105

McCann, E. (2011). Urban policy mobilities and global circuits of knowledge: Toward a research agenda. Annals of the Association of American Geographers, 101(1), 107-130. https://doi.org/10.1080/00045608. 2010.520219

McCann, E., \& Ward, K. (2013). A multi-disciplinary approach to policy transfer research: Geographies, assemblages, mobilities and mutations. Policy Studies, 34(1), 2-18. https://doi.org/10.1080/01442872. 2012.748563

McGreevy, M., \& Wilson, L. (2017). The civic and neighbourhood commons as complex adaptive systems: The economic vitality of the centre. Planning Theory, 16(2), 169-185. https://doi.org/10.1177/ 1473095216631587

Muldoon-Smith, K., \& Greenhalgh, P. (2016). Greasing the wheels, or a spanner in the works? Permitting the adaptive re-use of redundant office buildings into residential use in England. Planning Theory and Practice, 17(2), 175-191. https://doi.org/10.1080/14649357. 2016.1156144

Muldoon-Smith, K., \& Greenhalgh, P. (2017, June 28-July 1). Situations vacant: A conceptual framework for commercial real estate vacancy [Paper presentation]. European Real Estate Society Conference, Delft, The Netherlands.

O'Connor, S. (2020, November 23). The shift to remote work carries an inherent risk. Financial Times. https://www.ft.com/content/192eb45a-f7c9-4897ac56-57cb743ac2f2

Oswalt, P., Overmeyer, K., \& Misselwitz, P. (2013). Urban catalyst: The power of temporary use. DOM Publishers.

Patterson, T. M., Niccolucci, V., \& Marchettini, N. (2008). Adaptive environmental management of tourism in the province of Siena, Italy using the ecological footprint. Journal of Environmental Management, 86(2), 407-418. https://doi.org/10.1016/j.jenvman. 2006.04.017

Peck, J., \& Theodore, N. (2010). Mobilizing policy: Models, methods, and mutations. Geoforum, 41(2), 169-174. https://doi.org/10.1016/j.geoforum.2010. 01.002

Peck, J., \& Theodore, N. (2015). Fast policy: Experimental statecraft at the thresholds of neoliberalism. University of Minnesota Press.

Peck, J., \& Tickell, A. (2002). A neoliberalizing space. Antipode, 34(3), 380-404. https://doi.org/10.1111/ 1467-8330.00247

Portugali, J. (2011). A self-planned city. In J. Portugali (Ed.), Complexity, cognition, and the city (pp. 299-311). Springer.

Portugali, J. (2012). Complexity theories of cities: First, second or third culture of planning. In G. de Roo 
\& J. Hillier (Eds.), Complexity and planning: Systems, assemblages and simulations (pp. 117-140). Ashgate.

Raco, M., Durrant, D., \& Livingstone, N. (2018). Slow cities, urban politics and the temporalities of planning: Lessons from London. Environment and Planning C: Politics and Space, 36(7), 1176-1194. https:// doi.org/10.1177/2399654418775105

Remoy, H., \& Street, E. (2018). The dynamics of "postcrisis" spatial planning: A comparative study of office conversion policies in England and the Netherlands. Land Use Policy, 77, 811-820. https://doi.org/ 10.1016/j.landusepol.2016.12.005

Schulze-Bang, A., \& Webb, B. (2020). Planning through zoning. Royal Town Planning Institute. https://www.rtpi.org.uk/research/2020/ september/planning-through-zoning

Sengupta, U. (2011). Urban morphology: Incorporating complexity and variation. In I. Mironowicz \& J. Ryser (Eds.), Urban change: The prospect of transformation (pp. 180-189). UN-HABITAT and Wroclaw University of Technology.

Sengupta, U., Rauws, S. W., \& de Roo, G. (2016). Planning and complexity: Engaging with temporal dynamics, uncertainty and complex adaptive systems. Environment and Planning B: Planning and Design, 43(6), 970-974. https://doi.org/10.1177/ 0265813516675872

Skrimizea, E., Haniotou, H., \& Parra, C. (2018). On the "complexity turn" in planning: An adaptive rationale to navigate spaces and times of uncertainty. Planning Theory, 18(1), 122-142. https://doi.org/ $10.1177 / 1473095218780515$

Slow Movement. (2017). Slow cities and the slow movement. www.slowmovement.com/slow_cities.php

Suzuki, D. (2007). The sacred balance: Rediscovering our place in nature (3rd ed.). Greystone Books.

Temenos, C., \& McCann, E. (2013). Geographies of policy mobilities. Geography Compass, 7(5), 344-357. https://doi.org/10.1111/gec3.12063

Terryn, E., \& Boelens, L. (2013, July 15-19). Adaptive management and planning: The emergence of $a$ new role for policy evaluation [Paper presentation]. AESOP/ACSP 5th Joint Congress 2013: Planning for Resilient Cities and Regions, Dublin, Ireland. https:// biblio.ugent.be/publication/4121344

Tewdwr-Jones, M. (2012). Spatial planning and governance: Understanding UK planning. Palgrave Macmillan.

Town and Country Planning Association. (2020). White Paper: Planning for the Future. A response by The Town and Country Planning Association to the MHCLG consultation. https://www.tcpa.org.uk/ Handlers/Download.ashx?IDMF=81c990df-cc5a4f37-9bd4-6c74a80ee540

van Buuren, A., Driessen, P. P. J., Rijswick, M. V., Rietveld, P., Salet, W., Spit, T., \& Teisman, G. (2013). Towards adaptive spatial planning for climate change: Balancing between robustness and flexibility. Journal for European Environmental \& Planning Law, 10(1), 29-53. https://doi.org/10.1163/ 18760104-01001003

Waldrop, M. M. (1992). Complexity: The emerging science at the edge of order and chaos. Penguin Books.

Westley, F. (2002). The devil in the dynamics: Adaptive management on the front lines. In L. Gunderson \& C. S. Holling (Eds.), Panarchy: Understanding transformations in human and natural systems (pp. 333-360). Island Press.

Wood, A. (2015). Multiple temporalities of policy circulation: Gradual, repetitive and delayed processes of BRT adoption in South African cities. International Journal of Urban and Regional Research, 39(3), 568-580. https://doi.org/10.1111/1468-2427. 12216

World Health Organization. (2020). Covid-19 strategy update. https://www.who.int/publications/m/item/ covid-19-strategy-update

Zellner, M., \& Campbell, S. D. (2015). Planning for deeprooted problems: What can we learn from aligning complex systems and wicked problems? Planning Theory \& Practice, 16(4), 457-478. https://doi.org/ $10.1080 / 14649357.2015 .1084360$

\section{About the Authors}

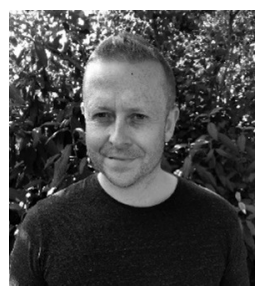

Kevin Muldoon-Smith is a lecturer in built environment adaptation and investment in the Department of Architecture and Built Environment at Northumbria University. He is particularly interested in the nature and reform of land and property and its relationship with the changing world of work. He investigates how new demand and legislative drivers are stranding property assets and how this threat can be countered through methods of adaptation.

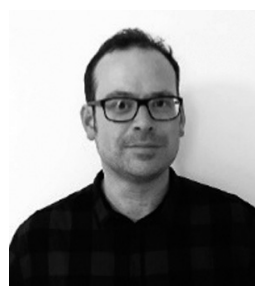

Leo Moreton is a researcher whose work is centered around new development in urban historic environments, examining approaches to design, integration, adaption, and amendment. He also looks at analogue and digital approaches to establish new design methodologies in the fields of architecture and urban planning. He particularly focuses on adaptive re-use, sustainability, and specification. 